\title{
Persepsi Dan Tingkat Kepuasan Petani Dalam Penggunaan Benih Padi Bersertifikasi Di Kecamatan Galang Kabupaten Deli Serdang
}

\author{
Desi Novita ${ }^{*}$ \\ Laras Andam Sari ${ }^{2}$ \\ Dian Hendrawan ${ }^{3}$ \\ 1,2,3 Program Studi Agribisnis, Fakultas Pertanian, Universitas Islam Sumatera Utara \\ *email: desi.novita@uisu.ac.id \\ Diterima: Agustus 2020, Disetujui: September 2020, Dipublish: Oktober 2020
}

\begin{abstract}
Abstrak
Benih adalah salah satu faktor yang menentukan keberhasilan produksi pertanian. Benih bersertifikasi merupakan salah satu cara untuk menunjukkan benih bermutu. Tujuan dari penelitian ini adalah untuk mengetahui persepsi dan tingkat kepuasan petani terhadap benih padi bersertifikasi. Lokasi penelitian di Kecamatan Galang Kabupaten Deli Serdang. Sampel dalam penelitian ini adalah petani yang menggunakankan benih padi bersertifikasi. Jumlah sampel dalam penelitian ini sebanyak 60 orang yang diambil secara sengaja (Purposive Sampling). Metode analisa data yang digunakan adalah analisis multi atribut Fishbein dan Indeks Kepuasan Konsumen (Customer Satisfaction Index/CSI). Hasil penelitian menunjukkan bahwa persepsi petani dalam menggunakan benih bersertifikasi disebabkan oleh atribut benih padi bersertifikasi bermutu. Selain itu, kemudahan dalam memperoleh benih serta produktivitas yang dihasilkan sangat baik menjadi faktor lain petani menggunakan benih bersertifikasi. Tingkat kepuasan petani dalam menggunakan benih sebesar 87,3 persen yang berarti bahwa petani sangat puas terhadap benih bersertifikasi. Atribut yang paling memuaskan petani yakni ketahanan benih terhadap rebah serta ketahanan benih terhadap hama penyakit.
\end{abstract}

Kata Kunci : Benih, Bersertifikasi, Kepuasan

\begin{abstract}
Seed is one of the factors that determine the success of agricultural production. Certified seeds are one way to show quality seeds. The purpose of this study was to determine the perceptions and level of satisfaction of farmers with certified rice seeds. Research location in Galang Sub District, Deli Serdang Regency. The number of samples in this study were 60 people who were taken intentionally (purposive sampling). The data analysis method used is the multi-attribute analysis of Fishbein and the Customer Satisfaction Index (CSI). The results showed that farmers' perceptions in using certified seeds were caused by the attributes of quality certified rice seeds. In addition, the ease of obtaining seeds and the resulting very good productivity are another factor for farmers to use certified seeds. The level of satisfaction of farmers in using seeds is 87.3 percent, which means that farmers are very satisfied with certified seeds. The most satisfying attributes of farmers are seed resistance to lodging and seed resistance to pests and diseases.
\end{abstract}

Keywords : Seeds, Certified, Satisfaction

\section{PENDAHULUAN}

Benih adalah satu satu faktor utama dalam menentukan keberhasilan dalam usahatani. Benih yang bermutu akan menentukan keberhasilkan produksi baik dari sisi kualitas maupun dari sisi kuantitas. Dengan benih yang bermutu maka akan mampu meningkatkan kesejahteraan petani melalui peningkatan produksi dan kualitas hasil panen petani. Benih bermutu ditunjukan dengan mutu fisik yang bersih, ukuran 
seragam, daya kecambah dan kecempatan tumbuh yang baik (Widajati dkk, 2012).

Di Indonesia, salah satu yang harus dilakukan untuk menunjukkan suatu benih bermutu atau tidak adalah dengan proses sertifikasi. Menurut Kementerian Pertanian (2019) mengatakan bahwa sertifikasi benih bertujuan untuk menegaskan bahwa benih yang digunakan di masyarakat adalah benih yang memang layak dan dijamin kualitasnya. Benih yang bersertifikasi merupakan benih yang sudah melalui mekanisme/ proses pengujian sehingga benih yang dihasilkan layak edar. Begitupun yang diterapkan dalam sistem perbenihan padi di Indonesia.

Benih padi merupakan salah satu benih yang menjadi fokus pemerintah Indonesia, dikarenakan padi adalah pangan utama. Berdasarkan data Kementrian Pertanian (2018), terdapat 1.672 varietas yang sudah dilepas yang terdiri dari varietas untuk komoditas padi, jagung, kedelai, kacang tanah, kacang hijau, ubi kayu, sorgum, dan lainnya. Pada tahun 2017, jumlah produksi benih padi bersertifikasi sebanyak 210.561 ton. Jumlah ini masih kurang $(54,93 \%)$, dibandingkan dengan kebutuhan benih padi yang mencapai 383.348 ton. Sementara itu, dari sisi varietas yang digunakan, varietas padi masih didominasi dengan varietas padi Ciherang (35,35\%), mekongga $(10,05 \%)$, IR 64 (7,96\%), serta varietas lokal (11,28\%).

Provinsi Sumatera Utara adalah salah satu provinsi yang menjadi sentra produksi padi sawah di Indonesia (Penghasil Padi Sawah ke 6 terbesar).
Produksi Padi Sawah di Sumatera Utara mengalami pertumbuhan sebesar 3,81\% pada tahun 2018 (BPS, 2019). Pada tahun 2018, produksi padi sawah mencapai 4.847 .748 ton dengan luas lahan 907.265 Ha. Dengan perbandingan ini, didapatkan produktivitas padi sawah di Sumatera Utara sebesar 5,34 Ton/Ha sedikit lebih rendah dibawah rata-rata nasional yang mencapai 5,35 ton/Ha.

Produktivitas padi ini dipandang masih belum optimal. Salah satu yang menjadi penyebab belum optimalnya produktivitas padi tersebut adalah penggunaan benih bersertifikasi yang belum merata dan belum maksimal. Masih banyak petani yang menggunakan benih tidak bersertifikasi alias benih yang digunakan petani berasal dari panen petani sebelumnya. Selain itu, menurut Nuswardhani (2019) dan Mayalibit dkk (2017), faktor pendidikan, pengalaman serta pengaruh ketokohan (contoh orang) menjadi faktor yang juga bisa membuat petani menggunakan benih bersertifikasi.

Salah satu kabupaten yang menjadi lumbung padi sawah di Sumatera Utara adalah kabupaten Deli Serdang. Berdasarkan data Dinas Tanaman Pangan dan Hortikultura (2020), terlihat bahwa masih terjadinya kekurangan benih bersertifikasi. Dari data menunjukkan bahwa masih terjadi kekurangan benih sebesar $1.318 .150 \mathrm{Kg}$ (2018), 1.424.900 Kg (2019), dan 1.779 .850 (2019).

Kecamatan Galang merupakan salah satu kecamatan yang berada di Kabupaten Deli Serdang yang memiliki produksi padi dibawah rata-rata dan dalam kondisi defisit beras (BPS, 2019). 
Salah satu hal yang harus dilakukan adalah meningkatkan produktivitas padi melalui penggunaan benih unggul yakni benih bersertifikasi. Akan tetapi, masih banyaknya petani menggunakan benih yang tidak bersertifikasi disebabkan petani masih enggan menggunakan benih bersertifikasi dengan alasan biaya pembelian benih serta kepercayaan petani terhadap benih bersertifikasi yang belum tinggi. Masih adanya petani yang berpendapat bahwa benih bersertifikasi belum tentu benih bermutu. Ada 4 hal yang menjadi wacana di masyarakat terkait dengan benih yakni (1) benih bermutu \& bersertifikasi, (2) benih bermutu tetapi tidak bersertifikasi, (3) benih tidak bermutu tetapi bersertifikasi, dan (4) benih tidak bermutu dan tidak bersertifikasi. Menurut Hendrawati (2014) dalam penelitiannya menyatakan bahwa persepsi petani dalam penggunaan benih padi unggul di Kecamatan Muara Pawan Kabupaten Ketapang dikategorikan dalam persepsi yang kurang baik karena disebabkan oleh penyediaan benih. Oleh sebab itu, perilaku petani dalam penggunaan benih bersertifikasi menjadi salah satu yang perlu dicermati agar dapat memahami bagaimana perilaku petani dalam berusahatani.

Secara lebih rinci, adapun tujuan dalam penelitian ini adalah untuk mengetahui persepsi petani dalam penggunaan benih padi sawah bersertifikasi di Kecamatan Galang dan mengetahui bagaimana tingkat kepuasan petani dalam penggunaan benih padi sawah bersertifikasi di Kecamatan Galang.

\section{METODE PENELITIAN}

Lokasi penelitian di Kecamatan Galang, Kabupaten Deli Serdang. Penentuan lokasi dan sampel dilakukan dengan secara sengaja (purposive Sampling). Pemilihan lokasi mempertimbangkan karena Kecamatan Galang merupakan salah satu daerah dengan produksi yang relatif rendah dan daerah dengan defisit beras. Penelitian ini dilakukan pada tahun 2019. Sampel yang digunakan dalam penelitian ini sebanyak 60 orang yaitu petani padi sawah yang menggunakan benih padi sawah yang bersertifikasi.

Penelitian ini menggunakan data yang bersifat data primer dan data sekunder. Data primer diperoleh dari hasil wawancara langsung dengan para petani padi sawah yang menggunakan benih padi sawah bersertifikasi. Wawancara dilakukan dengan menggunakan bantuan kuesioner. Kuesioner ini merupakan salah satu cara pengumpulan data dengan menggunakan seperangkat daftar pertanyaan tertulis yang harus dijawab oleh responden (Sugiyono, 2007). Data sekunder adalah data yang diperoleh dari instansi terkait seperti Dinas Pertanian Kabupaten Deli Serdang, Dinas Tanaman Pangan dan Hortikultura Provinsi Sumatera utara, Badan Penyuluh Pertanian serta Badan Pusat Statistik (BPS) Provinsi Sumatera Utara.

Metode analisa yang digunakan untuk mengukur sikap petani dalam penggunaan benih padi bersertifikasi yaitu Analisa Multiatribut Fishbein. Menurut (Sumarwan, 2011), model multiatribut fishbein mampu menjelaskan sikap petani terhadap suatu 
produk yakni benih padi bersertifikasi melalui atribut-atribut tertentu yang dievaluasi.

Secara simbolis model sikap Fishbein diformulasikan dalam bentuk:

$$
\left.A_{o}=\sum_{i-1}^{n} b_{i} \cdot e_{i} \ldots \ldots \ldots .1\right)
$$

Keterangan:

$$
\begin{array}{rll}
\text { Ao } \quad \text { : } & \text { Sikap terhadap bibit padi } \\
& \text { bersertifikasi } \\
\text { bi } \quad: \text { Tingkat kepercayaan bahwa } & \\
& \text { benih varietas memiliki } \\
& \text { atribut ke-i } \\
\text { ei } \quad: \text { Evaluasi kepentingan } & \text { terhadap atribut i } \\
\text { n } \quad: \text { Jumlah atribut yang } \\
\end{array}
$$

Tingkat kepuasan petani dianalisis dengan menggunakan metode Customer Satisfaction Index (CSI). Menurut (Starford 2004, diacu dalam Chanifah 2009) Indeks kepuasan pelanggan atau Customers Satisfaction Index (CSI) merupakan salah satu alat ukur yang dapat digunakan untuk mendukung peneliti agar mengetahui tingkat kepuasan petani secara menyeluruh dengan melihat tingkat kepentingan dari seluruh atribut benih padi.Ada empat langkah dalam perhitungan Consumers Satisfaction Index, yaitu:

a. Menentukan Means Important Score (MIS) dan Mean Satification Score(MSS) responden

$$
\begin{aligned}
& \text { MIS } \left.=\sum_{i=0}^{n} Y i \quad \ldots \ldots \ldots \ldots \ldots \ldots . . . .2\right) \\
& \text { MSS } \left.=\sum_{i=0}^{n} X i \quad \ldots \ldots \ldots \ldots \ldots . . . .3\right) \\
& \text { Keterangan : } \\
& \mathrm{N} \quad: \quad \text { Jumlah responden } \\
& \mathrm{Yi} \quad: \quad \text { Nilai kepentingan atribut ke i } \\
& \mathrm{Xi} \quad: \quad \text { Nilai kinerja atribut ke i }
\end{aligned}
$$

b. Menentukan nilai Weight Faktors (WF),

$$
W F=\frac{M I S i}{\sum_{i=1}^{i} Y i} x 100
$$

Keterangan :

$\mathrm{p} \quad$ : Jumlah atribut kepentingan

i : Atribut ke i

c. Menghitung nilai Weight Score (WS)

$$
\mathrm{WS}=\mathrm{WF} \times \mathrm{MSS}
$$

d. Menentukan Nilai Kepuasan

$$
\left.\mathrm{CSI}=\frac{\sum_{i=1}^{p} w S i}{\mathrm{HS}} \times 100 \% \ldots \ldots 6\right)
$$

Keterangan :

$$
\begin{array}{llll}
\mathrm{p} & : \text { Atribut ke } \mathrm{p} \\
\mathrm{HS} & : \text { Skala maksimum yang } \\
& & \text { ditetapkan }
\end{array}
$$

Kepuasan petani memggunakan suatu skala untuk menunjukan kriteria tingkat kepuasan konsumen terhadap sebuah produk. Rentang skala kepuasan berkisar antara $0 \%$ hingga 100\%. Menurut (Simamora, 2012) untuk membuat skala linier numerik dimulai dengan mencari Rentang Skala (RS) dengan rumus sebagai berikut :

$$
R s=\frac{\mathrm{m}-\mathrm{n}}{\mathrm{b}}
$$

Keterangan:

Rs : Rentang skala

M : Skor tertinggi

$\mathrm{N} \quad$ : Skor terendah

B : Jumlah kelas atau kategori yang telah ditetapkan

Tabel 1. Kriteria Penilaian CSI

\begin{tabular}{cc}
\hline Nilai CSI (\%) & Kriteria \\
\hline $0-20$ & Sangat Tidak Puas \\
$21-40$ & Tidak Puas \\
$41-60$ & Cukup Puas \\
$61-80$ & Puas \\
$81-100$ & Sangat Puas \\
\hline Supranto, J (2011) &
\end{tabular}


HASIL DAN PEMBAHASAN

\section{Karakteristik Petani dan Usahatani Padi Sawah}

Karakteristik petani dan usahatani padi sawah digambarkan pada Tabel 2 . Berdasarkan hasil penelitian terlihat bahwa usia petani padi sudah mendekati usia yang tidak produktif yakni mendekati usia 50 tahun. Kondisi ini tentu saja akan berdampak pada daya terima terhadap pengetahuan baru dan kinerja dalam usaha tani padi. Selain itu, tingkat pendidikan petani juga hanya sampai tingkat SMP.

Tabel 2. Karakteristik Petani Padi

\begin{tabular}{lc}
\multicolumn{1}{c}{ Kriteria } & Rata - Rata \\
\hline Usia (Tahun) & 46,5 \\
Tingkat Pendidikan & SMP \\
Lama Bertani (Tahun) & 18 \\
Frekuensi Tanam Padi/Tahun (Kali) & 2 \\
\hline
\end{tabular}

Sumber : Data Primer (Diolah)

\section{Persepsi Petani Terhadap Atribut Benih Padi Bersertifikat}

Tingkat kepentingan dalam penggunaan benih bersertifikasi yang digunakan untuk mengetahui sejauh mana setiap atribut dianggap penting oleh petani. Varietas benih sertifikasi yang digunakan adalah Ciherang dan Inpari. Tingkat kepentingan dilakukan melalui pemetaan dilakukan menggunakan nilai rata-rata (mean scores).

Tabel 3. Persepsi Responden terhadap Tingkat Kepentingan Atribut Benih Padi Bersertifikasi

\begin{tabular}{llcc}
\hline No & \multicolumn{1}{c}{ Atribut } & Mean Scores & Interpretasi \\
\hline 1. & Benih Bermutu & 4,83 & Sangat Penting \\
2. & Ketersediaan Benih & 4,63 & Sangat Penting \\
3. & Produktivitas & 4,43 & Sangat Penting \\
4. & Harga Jual & 4,40 & Sangat Penting \\
5. Pemasaran Hasil Panen & 4,37 & Sangat Penting \\
6. & Tahan Rebah Tanaman & 4,23 & Sangat Penting \\
7. Ketahanan Terhadap Hama dan Penyakit & 4,13 & Sangat Penting \\
8. & Harga Benih & 3,97 & Penting \\
9. Rasa Nasi & 3,97 & Penting \\
\hline
\end{tabular}

Sumber : Data Primer (Diolah)

Berdasarkan tabel 3, Petani berpendapat bahwa atribut yang terpenting dalam benih bersertifikasi adalah mutu benihnya. Kemudian diikuti oleh atribut ketersediaan benih. Hal ini berarti bahwa benih yang bersertifikasi yang ditunjukkan dengan label benih lebih bermutu dibanding benih yang tidak bersertifikasi.

Umumnya, benih padi sawah yang sering digunakan berlabel ungu dan putih. Benih yang dibudidaya diperoleh 
dari balai benih Pasar Miring dan penangkar lainnya yang menghasilkan label putih. Tujuh dari 9 atribut berada pada level sangat penting bagi sebuah produk benih padi sawah. Harga benih dan rasa benih berada pada level penting. Atribut kualitas benih, ketersediaan benih bersertifikasi dan produktivitas benih menjadi 3 atribut utama dalam penggunaan benih bersertifikasi.

\section{Analisis Sikap Petani terhadap Benih Bersertifikat}

Analisis sikap petani terhadap kedua varietas benih padi bersertifikat pada penelitian ini menggunakan analisis Multiatribut Fishbein. Model ini menjelaskan bagaimana sikap seorang konsumen terhadap suatu objek terhadap berbagai atribut yang dimiliki.

Berdasarkan hasil yang diperoleh rata-rata tingkat kepentingan dari atribut benih padi sebesar 4,33.
Sementara itu tingkat kinerja sebesar 3,24 . Nilai ini menunjukkan bahwa tingkat kepentingan yang diharapkan oleh petani terhadap benih bersertifikasi masih lebih tinggi dari kinerja dari setiap atributnya dimana nilai optimalnya adalah 5. Kondisi ini menunjukkan, bahwa harus ada pengoptimalan dari atribut benih padi agar kinerja yang dihasilkan sesuai kepentingan yang diharapkan. Sementara itu, hasil penelitian Prafithriasari (2017), menunjukkan antara tingkat kepentingan/harapan (rata rata 4,28) lebih rendah dari tingkat kinerja yang dihasilkan dari atribut benih padi (rata rata 4,32).

Perbedaan ini bisa saja disebabkan oleh pengelolaan budidaya yang belum optimal mengacu pada Good Agriculture Practice (GAP), serta permasalahan rantai pasok benih itu sendiri.

Tabel 4. Hasil Perhitungan Model Sikap Multiatribut Fishbein

\begin{tabular}{clcc}
\hline No & \multicolumn{1}{c}{ Atribut } & Ei & Bi \\
\hline 1. & Produktivitas & 4,43 & 3,43 \\
2. & Tahan Rebah Tanaman & 4,23 & 2,90 \\
3. & Benih Bermutu & 4,83 & 4,07 \\
4. & Rasa Nasi & 3,97 & 2,90 \\
5. & Ketahanan Terhadap Hama Penyakit & 4,13 & 2,53 \\
6. & Ketersediaan Benih & 4,63 & 4,10 \\
7. & Harga Benih & 3,97 & 3,00 \\
8. & Harga Jual Hasil Panen & 4,40 & 3,13 \\
9. & Pemasaran Hata-rata & 4,37 & 3,07 \\
\hline
\end{tabular}

Sumber : Data Primer (Diolah)

Atribut yang dinilai sangat penting oleh para petani responden adalah benih yang bermutu serta keterjaminan ketersediaan benih. Bagi petani, benih bersertifikasi berarti benih tersebut sudah memiliki keterjaminan terhadap mutu yang dihasilkan. Hal ini senada dalam penelitian Syamsiah (2015) yang menyatakan bahwa benih bersertifikasi mampu menghasilkan mutu yang baik dari sisi produktivtas dan tahan terhadap hama dan penyakit. Selain itu, 
ketersediaan benih yang ada juga mudah untuk didapat baik itu di toko tani dan juga dari penangkar benih berlabel putih serta adanya balai benih yang berada di Kecamatan Galang.

\section{Kepuasan Petani terhadap Benih Padi Bersertifikasi}

Berdasarkan hasil perhitungan dalam Customer Satisfaction Index (CSI) didapat hasil kepuasan petani terhadap benih bersertifikasi. Berdasarkan hasil perhitungan CSI, maka tingkat kepuasan petani terhadap benih bersertifikasi sebesar 87,3 persen. Nai ini menunjukkan bahwa petani sangat puas terhadap berbagai atribut yang terdapat pada benih bersertifikasi. Tingkat ketahanan benih terhadap rebah dan terhadap hama penyakit menjadi indikator terbaik yang memuaskan petani dalam menggunakan benih bersertifikasi, yakni :

Tabel 5. Perhitungan Customers Satisfaction Index pada Benih Padi Bersertifikat

\begin{tabular}{clcccc}
\hline No & \multicolumn{1}{c}{ Atribut } & MIS & MSS & WF & WS \\
\hline 1 & Produktivitas & 4,43 & 2,43 & 11,38 & 39,06 \\
2. & Tahan Rebah Tanaman & 4,23 & 4,07 & 10,86 & 50,44 \\
3. & Benih Bermutu & 4,83 & 2,90 & 12,40 & 29,52 \\
4. & Rasa Nasi & 3,97 & 2,53 & 10,18 & 26,87 \\
5. & Ketahanan Terhadap Hama Penyakit & 4,13 & 4,10 & 10,61 & 48,75 \\
6. & Ketersediaan Benih & 4,63 & 3,00 & 11,89 & 30,54 \\
7. & Harga Benih & 3,97 & 3,13 & 10,18 & 35,38 \\
8. & Harga Jual & 4,40 & 3,07 & 11,29 & 34,37 \\
9. & Pemasaran Hasil Panen & 4,37 & 4,37 & 11,21 & 0,00 \\
\hline \multicolumn{2}{c}{ Total } & 38,97 & Weight Average Total & 731,60 \\
\hline & CSI & \multicolumn{4}{c}{$\mathbf{8 7 , 3}$} \\
\hline
\end{tabular}

Sumber : Data Primer (Diolah)

Nilai CSI ini lebih rendah dari hasil penelitian Prafitriasari (2017), dimana nilai CSI sebesar 94\%. Perbedaan mendasarkan penelitian tersebut dengan penelitian saat ini adalah pada varietas benih bersertifikasi. Umumnya di Kecamatan Galang, petani menggunakan benih padi Ciherang dan Mengkongga, sementara dalam penelitian Prafithriasari (2017) tersebut adalah benih padi Pandanwangi.

\section{SIMPULAN}

Tingkat kepentingan/harapan terhadap atribut benih masih lebih rendah daripada kinerja dari atribut benih padi. Atribut petani dalam menggukana benih bersertifikasi disebabkan kualitas benih, ketersediaan benih yang mudah didapat, serta produktivitas dari benih bersertifikasi. Disisi lain, berdasarkan hasil perhitungan Customer Satisfaction Index (CSI), petani padi sawah merasa sangat puas terhadap benih bersertifikasi. Atribut utama yang menyebabkan petani sangat puas dalam menggunakan benih bersertifikasi adalah faktor ketahanan benih terhadap rebah, ketahanan terhadap hama penyakit serta produktivitas dari benih yang baik.

\section{DAFTAR PUSTAKA}

Badan Pusat Statistik. 2019. Produk, Luas Panen, dan Produktivitas Padi di Indonesia 2014-2018. 
Badan Pusat Statistik. Jakarta. 2019.

Badan Pusat Statistik. 2019. Kabupaten Deli Serdang dalam Angka 2018. Badan Pusat Statistik. Deli Serdang. 2019

Chanifah. 2009. Analisis Sikap dan Kepuasan Petani Terhadap Atribut Benih Padi Hibrida (Kasus Kecamatan Pamijahan Kabupaten Bogor Jawa Barat). [skripsi]. Bogor: Fakultas Ekonomi dan Manjemen, Institut Pertanian Bogor.

Hendrawati, Elly.dkk. 2014. Analisis Persepsi Petani dalam Penggunaan Benih Padi Unggul di Kecamatan Muara Pawan Kabupaten Ketapang. Jurnal Social Economic of Agriculture. Volume 3, Nomor 1.

Kementerian Pertanian. 2019. http://bbppmbtph.tanamanpang an.pertanian.go.id.

Kementerian Pertanian. 2018. http://balitkabi.litbang.pertanian go.id.

Mayalibit, dkk. 2017. Sikap Petani Padi Bersertifikat di Kecamatan Karangpandan, Kabupaten Karanganyar. Journal of Sustainable Agriculture. Volume 32, No 2.

Nuswardhani,S.K. dan Arief, Bidjaksana. 2019. Kajian Serapan Benih Padi Bersertifikasi di Indonesia
Periode 2012-2017. Jurnal Agrika: Jurnal Ilmu-Ilmu Pertanian, Volume 12, Nomor 2.

Prafithriasari, M. dan Fathiyakan, G. 2017. Analisis Sikap dan Kepuasan Petani dalam Menggunakan Benih Padi Varietas Lokal Pandanwangi. Agroscience Volume 7 No.2.

Simamora, B. 2012. Panduan riset Prilaku konsumen. PT Gramedia pustaka, Jakarta

Sugiyono. 2007. Metode Penelitian Bisnis. Bandung: Alfabeta

Supranto, J. 2011. Pengukuran Tingkat Kepuasan Pelanggan: Untuk Menaikkan Pangsa Pasar. Rineka Cipta. Jakarta.

Sumarwan, Ujang. 2011. Perilaku Konsumen: Teori dan Penerapannya dalam Pemasaran. Bogor: Ghalia Indonesia

Supranto, J. 2011. Pengukuran Tingkat Kepuasan Pelanggan Untuk Menaikkan Pangsa Pasar, Cetakan keempat, Penerbit PT Rineka Cipta, Jakarta

Syamsiah, S. dkk. 2015. Analisis Sikap Petani terhadap Penggunaan Benih Varietas Unggul di Kabupaten Subang Jawa Barat. Jurnal AGRISE Volume XVI No.3.

Widajati, E., E. Murniati, E.R.Palupi, T. Kartika, M.R. Suhartanto dan A. Qodir. 2012. Dasar Ilmu dan Teknologi Benih. Bogor: IPB Press. 